\title{
Depth attenuation of organic matter export associated with jelly falls
}

\author{
Mario Lebrato, ${ }^{\mathrm{a},{ }^{*}}$ Markus Pahlow, ${ }^{\mathrm{a}}$ Andreas Oschlies, ${ }^{\mathrm{a}}$ Kylie A. Pitt, ${ }^{\mathrm{b}}$ Daniel O. B. Jones, ${ }^{\mathrm{c}}$ \\ Juan Carlos Molinero, ${ }^{a}$ and Robert H. Condond
}

\author{
${ }^{a}$ Leibniz Institute of Marine Science (IFM-GEOMAR), Kiel, Germany \\ b Australian Rivers Institute, Coast and Estuaries, Griffith University, Gold Coast Campus, Australia \\ c National Oceanography Centre, Southampton, United Kingdom \\ dDauphin Island Sea Lab, Dauphin Island, Alabama
}

\begin{abstract}
We explore the attenuation in the export ratio of jelly-POM (particulate organic matter) with depth as a function of the decay rate, temperature, and sedimentation rate. Using data from the Vertical Transport In the Global Ocean project, we compare ratios computed with the Martin-curve, with a particle-based parameterization, and with sediment-trap data. Owing to the temperature dependence of the decay rate $\left(Q_{10}=4.28\right)$, the jelly-POM export ratio below $500 \mathrm{~m}$ is $20-45 \%$ larger in subpolar and temperate areas than in the tropics. Vertical migration of gelatinous zooplankton leads to a variable starting depth of a jelly fall (death depth), which governs the start of remineralization, and the fate of the biomass. Owing to the absence of observations, we employ a sinking speed matrix ranging from $100 \mathrm{~m} \mathrm{~d}^{-1}$ to $1500 \mathrm{~m} \mathrm{~d}^{-1}$ to represent slow- and fast-sinking carcasses. The assumption of a constant decay rate $k$ independent of temperature in other particle-based models may not be appropriate. These results provide information for including jelly-POM in global biogeochemical model formulations.
\end{abstract}

Particulate and gelatinous material export-Vertical fluxes of biogenic and particulate organic matter (POM) govern chemical gradients and, thus, drive the ocean's biological carbon pump. Sinking POM varies in size and composition, originating in every trophic level as exudates, detritus, fecal material, aggregates, biogenic carbonates, or the carcasses of the organisms themselves (Turner 2002). The remineralization profile of POM generally depends on the sinking speed (McDonnell and Buesseler 2010) and the decay rate (Martin et al. 1987). The contribution of gelatinous zooplankton to POM export has been assessed for detrital particles and fecal pellets (Turner 2002). The fate of the biomass of gelatinous organisms (jelly-POM), mainly from Cnidaria and Thaliacea, however, has been rarely assessed and, thus, not included in biogeochemical models. Yet, there is substantial evidence of sedimentation events in the last decades, so-called 'jelly falls,' that can deposit large amounts of biomass on the seafloor (Lebrato and Jones 2009). Remineralization of gelatinous material releases dissolved organic matter (jelly-DOM), creating a 'jelly carbon shunt' (Condon et al. 2011). Inorganic nutrients are also released (Pitt et al. 2009) and oxygen is consumed (West et al. 2009). Thus, remineralization of jelly falls has broad biogeochemical implications, similar to other sinking particles, although the different biochemical composition $(\mathrm{C}: \mathrm{N}: \mathrm{P})$ and the absence of mineral ballast imply different stoichiometric relationships.

Jelly-POM representation in biogeochemical modelsThe parameterization of sinking organic matter in regional and large-scale biogeochemical models has evolved from the early use of static remineralization profiles, and the depth dependence of the flux of sinking particles. Recent

\footnotetext{
* Corresponding author: mlebrato@ifm-geomar.de
}

work on sinking particles, covering a size range of about $1-$ $1000 \mu \mathrm{m}$, is not truly applicable for the size spectrum of particles found in jelly falls (millimeters to meters). The sedimentation of POM has been modeled using constant rates or an acceleration with depth, which can be related to the Martin et al. (1987) formulation. Observations of sinking material are limited to particles whose size fractions are small enough $(<1 \mathrm{~mm}$ to $\sim 50 \mathrm{~mm})$ to be collected by sediment traps. However, larger particles (such as those associated with jelly falls) have rarely been investigated (salps: $\sim 100-800 \mathrm{~m} \mathrm{~d}^{-1}$, siphonophores: $\sim 200 \mathrm{~m} \mathrm{~d}^{-1}$ [Apstein 1910]). Information on carcasses from other organisms could give an indication of jelly-POM sinking rates (e.g., cladocerans: $\sim 140 \mathrm{~m} \mathrm{~d}^{-1}$, amphipods: $\sim 900 \mathrm{~m} \mathrm{~d}^{-1}$, chaetognaths: $\sim 400 \mathrm{~m} \mathrm{~d}^{-1}$, copepods: 30 $700 \mathrm{~m} \mathrm{~d}^{-1}$ [Kuenen 1950]). The sedimentation rate of jellyPOM is governed by a combination of size, diameter, biovolume, and geometry (Walsby and Xypolyta 1977), material density (Yamamoto et al. 2008), and drag coefficients (McDonnell and Buesseler 2010). For large gelatinous carcasses (e.g., 100-200 kg Nemopilema nomurai carcasses), the weight per se dominates over any other forcing. Owing to their size, gelatinous carcasses sink individually, and do not coagulate as smaller particles do. Coagulation may occur during decomposition, however, when the material accumulates in high densities, forming mats at the seabed (Billett et al. 2006).

Although scyphozoans and thaliaceans sometimes occur on the seabed in enormous numbers, other gelatinous taxa, such as ctenophores and hydrozoans, have never been observed. This implies that the transfer efficiency of gelatinous biomass varies among taxa. The attenuation concept (Buesseler and Boyd 2009) motivated the current study. Here, we examine the remineralization of gelatinous biomass to assess the fraction arriving at a given reference 
Table 1. Data for the decay rate $(k)$ vs. temperature relationship used in Eq. 2.

\begin{tabular}{|c|c|c|c|c|c|c|}
\hline Organism & Species & Weight (g) & Depth (m) & $\begin{array}{c}\text { Experimental } \\
\text { temperature }\left({ }^{\circ} \mathrm{C}\right)\end{array}$ & $K^{*}$ & Reference \\
\hline Scyphozoan & N. nomurai & 955 & 2.5 & 8 & 0.513 & Iguchi et al. $2006 \$$ \\
\hline Scyphozoan & N. nomurai & 884 & 10 & $2.7 \dagger$ & 0.215 & Iguchi et al. 2006: \\
\hline Scyphozoan & P. periphylla & 300 & 8 & 12.5 & 0.844 & Titelman et al. 2006 \\
\hline Scyphozoan & P. periphylla & 223 & 1 & 10.1 & 0.666 & Titelman et al. 2006 \\
\hline Scyphozoan & P. periphylla & 121 & 1 & 10 & 0.716 & Titelman et al. 2006 \\
\hline Salpa & T. democratica & - & 1 & 16.5 & 1.600 & Sempere et al. 2000 \\
\hline
\end{tabular}

* The temperature coefficient $Q_{10}\left[Q_{10}=\left(R_{2} / R_{1}\right)^{10 /\left(T_{2}-T_{1}\right)}\right]$, where $R$ is reaction rate, and $T$ is temperature, varies between 4 and 5.20 depending on the pairs used. $Q_{10}=4.28$ using the initial $\left(2.7^{\circ} \mathrm{C}\right)$ and final temperature $\left(16.5^{\circ} \mathrm{C}\right)$.

$\dagger$ Intake water from $334 \mathrm{~m}$ into a tank at 10-m depth (therefore, microbial population retained).

\$ Full citation in http://jsnfri.fra.affrc.go.jp/Kurage/kurage_hp18/Sado_bunkai.pdf.

depth and/or at the seafloor (jelly-POM export ratio). In the following, we present a model parameterization describing two processes: The relationship between watercolumn temperature and decay rate $\left[k_{(T)}\right]$ for gelatinous material, and, hence, a temperature-dependent remineralization time scale (referred to as $t_{0.01}$ ), and a jelly-POM export ratio $\left[M\left(z_{\mathrm{R}}\right): M\left(z_{\mathrm{D}}\right)\right]$ (e.g., the proportion of jellyPOM originating from a death depth $z_{\mathrm{D}}$ and arriving at a reference depth $z_{\mathrm{R}}$ while sinking at constant velocity). Owing to the lack of empirical data, we consider a spectrum of sinking rates from $100 \mathrm{~m} \mathrm{~d}^{-1}$ to $1500 \mathrm{~m} \mathrm{~d}^{-1}$, representing different jelly-POM functional groups and size classes. A novel aspect is the use of POM remineralization profiles as a function of the vertical thermal gradient, which can be expanded to other kinds of particles. We also extend the parameterization of Kriest and Oschlies (2008) by varying the decay rate $(k)$, and examining a sinking-speed matrix of $20 \mathrm{~m} \mathrm{~d}^{-1}$ to $2000 \mathrm{~m} \mathrm{~d}^{-1}$ to represent gelatinous biomass. The modeled jelly-POM export ratio is compared with that predicted by the Martin curve (Martin et al. 1987) using field data from the Vertical Transport In the Global Ocean (VERTIGO) project (Buesseler et al. 2007). Model-data and model-model differences are analyzed to establish the theoretical grounds for further exploration of the jellyPOM remineralization concept.

\section{Methods}

Decay rate $(\mathrm{k})$ and remineralization times scale $\left(\mathrm{t}_{0.01}\right)$ At any given temperature, the initial decomposition of thaliacean and cnidarian carcasses by bacteria is followed by a progressive decrease in the remineralization rate attributed to a loss in lability of the jelly-material. During experimental work, $>80 \%$ of the carbon and nitrogen are remineralized within 5-8 d (Titelman et al. 2006). This indicates the lack of a refractory organic-matter pool (negligible contribution) that would justify the use of a second-order kinetic decay constant. Salps have a larger C:N than scyphozoans (Lucas et al. 2011), which could delay remineralization, but the decay rate seems to be comparable across groups as a function of temperature $\left(Q_{10}=4.28\right.$ using experimental initial and final temperatures; Table 1). Therefore, the assumption of a single firstorder kinetic decay constant for all gelatinous biomass may be justified (Table 1; Fig. 1A). In this model, the decay rate at time $t$ is the product of mass and the first-order decay constant $k$, which is a function of temperature. A second assumption owing to the lack of empirical data is a sizeindependent decay rate of jelly-POM as observed for macroaggregates (Ploug and Grossart 2000) and assumed in other models. The differential equation for jelly-POM biomass $M$ is

$$
d M / d t=-M k_{(T)}
$$

with

$$
k_{(T)}=0.140 \mathrm{day}^{-1} e^{0.145 T(z)}
$$

where $M$ is the jelly-POM at time $t, k_{(T)}$ is the temperaturedependent decay rate (in $\mathrm{d}^{-1}$ ), and $T(z)$ is temperature in ${ }^{\circ} \mathrm{C}$ at depth $z$. The coefficients in Eq. 2 were obtained from empirical observations (Fig. 1A). For constant temperature (T) Eq. 1 has the following solution:

$$
M_{1}=M_{0} e^{-k(T) t}
$$

where $M_{0}$ and $M_{1}$ are initial and final biomass at time $t$.

We define the remineralization time scale $t_{0.01}$ (in d) as the time it will take for $99 \%$ of the initial biomass to decompose at a specific temperature:

$$
t_{0.01}=-\ln (0.01) / k_{(T)}
$$

with $k_{(T)}$ given by Eq. 2, we obtain

$$
t_{0.01}=-\ln (0.01) /\left(0.140 \mathrm{day}^{-1} e^{0.145 T(z)}\right)
$$

Temperature data were compiled from hydrographic transects in the Atlantic and Pacific Oceans from $0 \mathrm{~m}$ to $6000 \mathrm{~m}$ (World Ocean Circulation Experiment data accessed at the Climate Variability and Predictability, and Carbon Hydrographic Data office from cruise line A16N [04 Jun to 11 Aug 2003] and A16S [11 Jan to 24 Feb 2005] in the Atlantic and P16N [13 Feb to 29 Mar 2006] and P16S [09 Jan to 19 Feb 2005] in the Pacific). Data were gridded using the minimum curvature method with 62 field lines (spacing of $3^{\circ}$ ) along the $\mathrm{x}$-axis (latitude) and 129 field lines (spacing of $50 \mathrm{~m}$ ) along the $\mathrm{z}$-axis (depth) from $60^{\circ} \mathrm{N}$ to $60^{\circ} \mathrm{S}$ and from $0 \mathrm{~m}$ to $6000 \mathrm{~m}$. Data were treated with the software Surfer v8 TM (Golden Software 2002). 


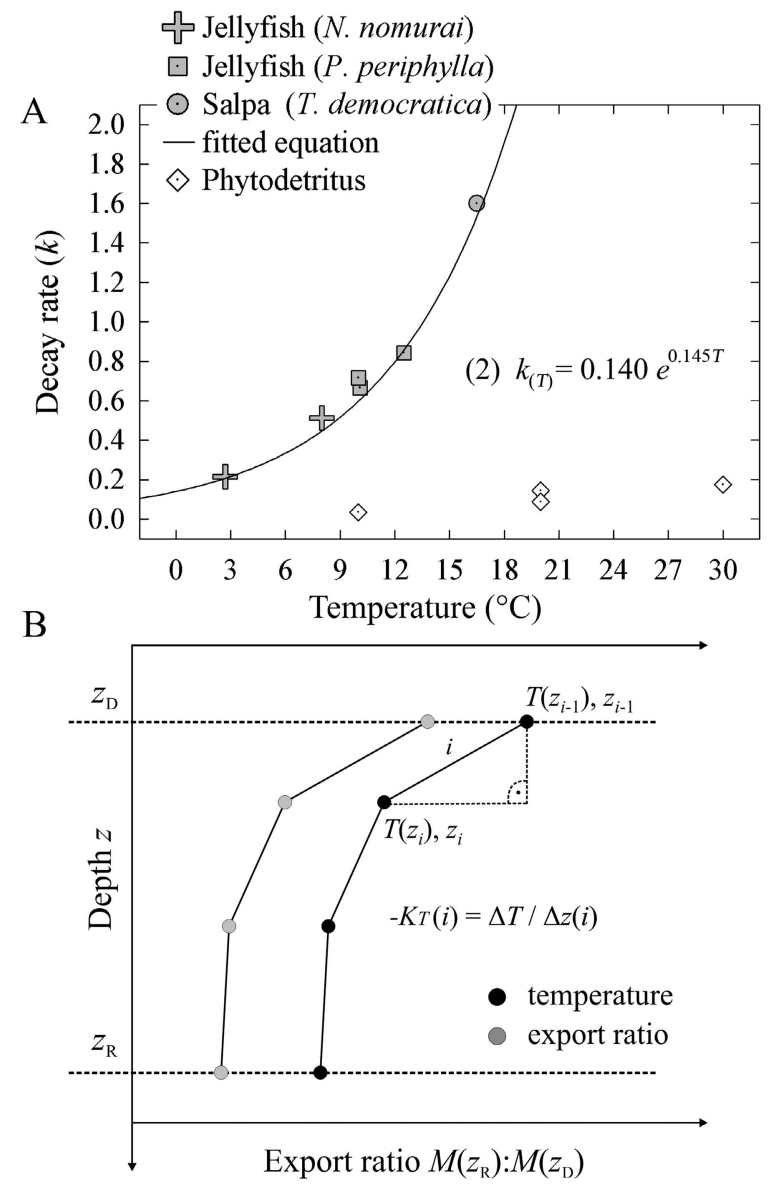

Fig. 1. (A) Parameterization of the decay rate $\left[k_{(T)}\right]$ of gelatinous material (jelly-POM [cnidarians and thaliaceans]) and the in situ temperature. Data were compiled from literature studies (Table 1). For comparison, $k$ data from phytoplankton studies where material was left degrading (phytodetritus) at different temperatures over time is included $\left(10^{\circ} \mathrm{C}\right.$ : Chlorophyta [Sudo et al. 1978], $20^{\circ} \mathrm{C}$ : Diatoms [Fujii et al. 2002], $30^{\circ} \mathrm{C}$ : Chlorophyta [Sudo et al. 1978]). (B) Piece-wise linear calculation of export ratio. The depth range between death depth $z_{\mathrm{D}}$ and reference depth $z_{\mathrm{R}}$ is divided into intervals bounded by $z_{i-1}$ and $z_{i}$, within which a linear temperature gradient $K_{T}(i)$ is assumed.

Jelly-POM export ratio $\left[\mathrm{M}\left(\mathrm{z}_{R}\right): \mathrm{M}\left(\mathrm{z}_{D}\right)\right]$-Ecological considerations: The downward transfer of gelatinous material starts from the depth where gelatinous zooplankton die (death depth $\left[z_{\mathrm{D}}\right]$ in the following). Our model uses the export ratio $\left[M\left(z_{\mathrm{R}}\right): M\left(z_{\mathrm{D}}\right)\right]$, relating an initial biomass $\left[M\left(z_{\mathrm{D}}\right)\right]$ sinking from a depth $z_{\mathrm{D}}$ with temperature $T\left(z_{\mathrm{D}}\right)$, to a final amount $\left[M\left(z_{\mathrm{R}}\right)\right]$ at depth $z_{\mathrm{R}}$ with temperature $T\left(z_{\mathrm{R}}\right)$. The parameters $z_{\mathrm{R}}$ and $T\left(z_{\mathrm{R}}\right)$ represent any reference depth in the water column (or seabed; Fig. 1B). The use of $z_{\mathrm{D}}$ is similar to the euphotic-zone depth concept ( $E z$; Buesseler and Boyd 2009). In contrast to $E z, z_{\mathrm{D}}$ variability is governed by the organisms' vertical migration distributing the biomass. Therefore, values for $z_{\mathrm{D}}$ vary between the euphotic zone and the lower level of the migratory range (taxon and species-specific). Pyrosomids migrate to near the seabed (Andersen and Sardou 1994). Salps migrate from the euphotic zone down to $400-800 \mathrm{~m}$ and, in some cases, to 1200-1800 m (Franqueville 1971). Living salps have been observed resting on the seabed (Gili et al. 2006). Cnidaria generally remain in the upper water column, although this is not always the case (e.g., hydrozoans), and large populations exist in the mesopelagic and bathypelagic zone. Ctenophores remain in the upper water column $(0-80 \mathrm{~m})$ with migration amplitudes between $20 \mathrm{~m}$ and $30 \mathrm{~m}$ (Huwer et al. 2008), but in some cases $250-600 \mathrm{~m}$ (Roe et al. 1984), or even down to the seabed. Therefore, we defined two scenarios for $z_{\mathrm{D}}$ : a general case applicable for sinking from the top of the euphotic zone between $0 \mathrm{~m}$ and $20 \mathrm{~m}\left(z_{\mathrm{D}}\right)$ down to $100-5000 \mathrm{~m}\left(z_{\mathrm{R}}\right)$, and a case taking into account vertical migration using a $z_{\mathrm{D}}$ between $100 \mathrm{~m}$ and $1000 \mathrm{~m}$ and $\mathrm{a} z_{\mathrm{R}}$ of $1000 \mathrm{~m}$ or $3000 \mathrm{~m}$.

Calculations of the export ratio $\left[\mathrm{M}\left(\mathrm{z}_{R}\right): \mathrm{M}\left(\mathrm{z}_{D}\right)\right]-\mathrm{We}$ approximate the temperature profile in the ocean by a piece-wise linear function dividing the depth range between $z_{\mathrm{D}}$ and $z_{\mathrm{R}}$ into $n$ discrete intervals (Fig. 1B). We used thermocline data at large scale (Table 2); thus, at local and regional scales, in situ temperature data could be resolved by smaller depth intervals. For each depth interval $i$, a linear temperature gradient was assumed between depths $z_{i-1}$ and $z_{i}\left(i \in[1 ; n], z_{0}=z_{\mathrm{D}}, z_{n}=z_{\mathrm{R}}\right)$. The corresponding temperatures $T\left(z_{i-1}\right)$ and $T\left(z_{i}\right)$ were obtained from transect observations and averaged for each latitude band from the corresponding depths using a search window of $\pm 20 \mathrm{~m}$ for $0-500 \mathrm{~m}$, and $\pm 200 \mathrm{~m}$ for $1000-5000 \mathrm{~m}$ (Table 2). For $z_{\mathrm{D}}$ $=0 \mathrm{~m}$, we used data only from $0 \mathrm{~m}$ to $20 \mathrm{~m}$. Temperature data points $T(z)$ were calculated as the average of all data points within each search window (Table 2). For each linear section, the vertical temperature gradient $z_{i-1}$ and $z_{i}$ is represented by $K_{T}(i)$ (Fig. 1B; Table 2):

$$
T\left(z_{i}\right)=T\left(z_{i-1}\right)+K_{T}(i)\left(z_{i}-z_{i-1}\right)
$$

and

$$
K_{T}(i)=\Delta T(i) / \Delta z(i)
$$

where $\Delta T(i)=T\left(z_{i}\right)-T\left(z_{i-1}\right)$ and $\Delta z(i)=z_{i}-z_{i-1}$. Within the linear section and for constant sinking speed $C$, the temperature can now be written as a function of time:

$$
T\left(z_{i}\right)=T\left(z_{i-1}\right)+K_{T}(i) \Delta t C
$$

where $\Delta t$ is the time it takes the particle to sink from depth $z_{i-1}$ to depth $z_{i}$.

The decay rate of jelly-POM over the linear section $i$ is obtained by substituting Eq. 8 into Eq. 2 and integrating (see Web Appendix: www.aslo.org/lo/toc/vol_56/issue_5/ 1917a.pdf for full solutions).

$$
M\left(z_{i}\right): M\left(z_{i-1}\right)=e^{\left[\frac{-0.1400^{0.145 T\left(z_{i-1}\right)}}{0.145 K^{(i) C}}\left(e^{0.145 K_{T}(i) \Delta t c}-1\right)\right]}
$$

The export ratio is then calculated as the product of the individual decay ratios of all linear sections $i$ :

$$
M\left(z_{\mathrm{R}}\right): M\left(z_{\mathrm{D}}\right)=\prod_{i=1}^{n} M\left(z_{i}\right): M\left(z_{i-1}\right)
$$

Owing to the absence of sinking speed observations, we 


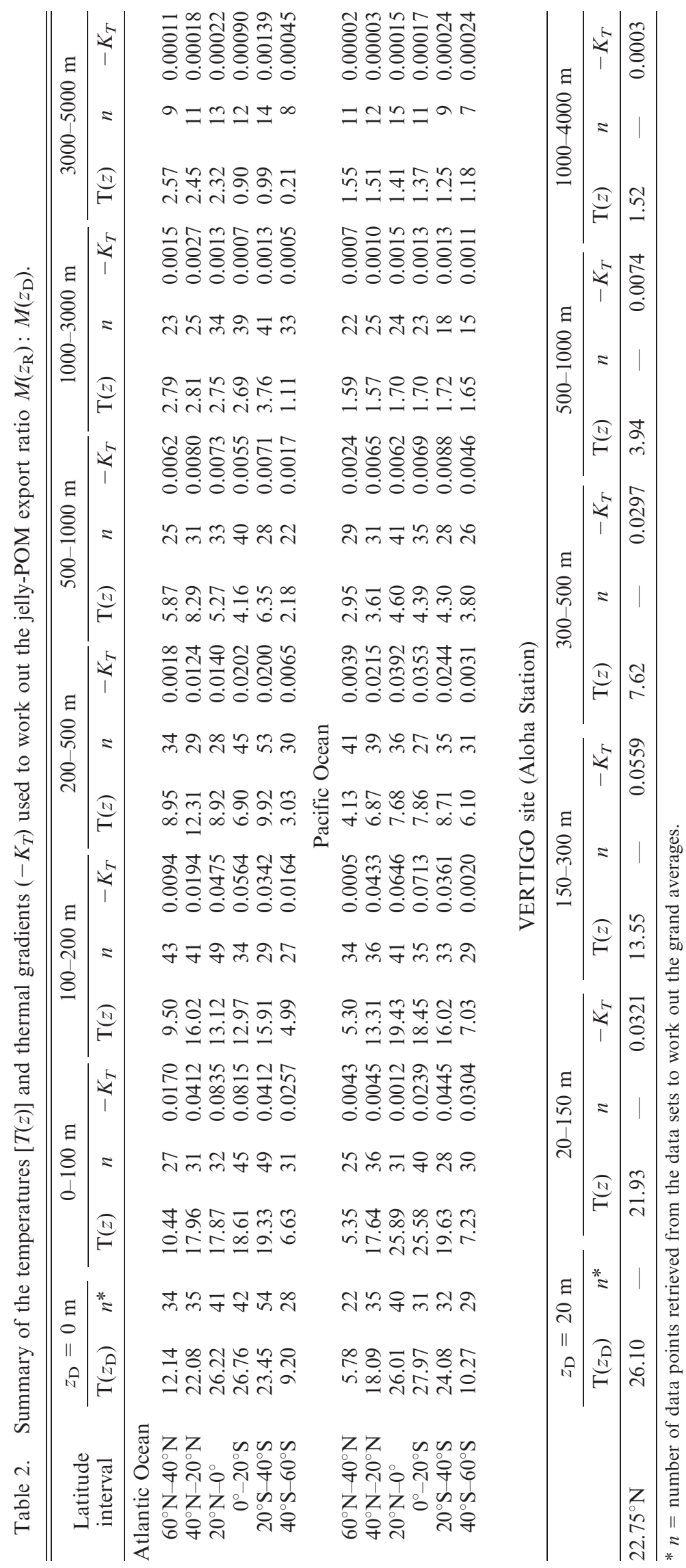


chose five (depth invariant) sinking speeds $(C)$ from $100 \mathrm{~m} \mathrm{~d}^{-1}$ to $1500 \mathrm{~m} \mathrm{~d}^{-1}\left(100 \mathrm{~m} \mathrm{~d}^{-1}\right.$ for ctenophores and hydromedusae, $300 \mathrm{~m} \mathrm{~d}^{-1}$ and $500 \mathrm{~m} \mathrm{~d}^{-1}$ for increasing size classes and some scyphomedusae, $800 \mathrm{~m} \mathrm{~d}^{-1}$ for scyphomedusae and thaliaceans in general, and $1500 \mathrm{~m} \mathrm{~d}^{-1}$ for fast-sinking material). In order to compare jelly-POM to particle-based export ratios, we extended the matrix (below $100 \mathrm{~m} \mathrm{~d}^{-1}$ and above $1500 \mathrm{~m} \mathrm{~d}^{-1}$ ) using VERTIGO project data (see below).

Comparison with a particle-based parameterization and the Martin curve-We compare the jelly-POM export ratios with a particle-based formulation for particles of a single size class (Kriest and Oschlies 2008):

$$
M\left(z_{\mathrm{R}}\right): M\left(z_{\mathrm{D}}\right)=e^{-k\left(z_{\mathrm{R}}-z_{\mathrm{D}}\right) / C}
$$

where $k$ is the remineralization rate (set to $0.03 \mathrm{~d}^{-1}$, varied from $0.01 \mathrm{~d}^{-1}$ to $0.05 \mathrm{~d}^{-1}$, and assumed to be independent of size and temperature), $z_{\mathrm{D}}$ and $z_{\mathrm{R}}$ are initial and reference depth, and $C$ is the sinking speed for an individual size class (originally set to $<0.05 \mathrm{~m} \mathrm{~d}^{-1}$ ). To make this formulation comparable to the jelly-POM model, we used a $10 \times 10$ matrix of $k\left(0.05-5 \mathrm{~d}^{-1}\right)$ and $C\left(20-2000 \mathrm{~m} \mathrm{~d}^{-1}\right.$; Table 3). We also compared the jelly-POM export ratio to the Martin curve formulation (Martin et al. 1987), which, for a constant remineralization rate, implies a POM sinking velocity increasing linearly with depth:

$$
M\left(z_{\mathrm{R}}\right): M\left(z_{\mathrm{D}}\right)=\left(z_{\mathrm{R}} / z_{\mathrm{D}}\right)^{-k: a}
$$

where $k: a$ (set at 0.858 ) is a ratio of a constant remineralization rate $(k)$ over a coefficient $a$ derived from fitting to field data. We used temperature data from the VERTIGO project at the ALOHA station $\left(22^{\circ} 45^{\prime} \mathrm{N}\right.$, $158^{\circ} \mathrm{W}$ ) in the Pacific Ocean (Buesseler et al. 2007) at depths of $20 \mathrm{~m}, 150 \mathrm{~m}, 300 \mathrm{~m}, 500 \mathrm{~m}, 1000 \mathrm{~m}$, and $4000 \mathrm{~m}$. We also used sediment-trap data (at $150 \mathrm{~m}, 300 \mathrm{~m}, 500 \mathrm{~m}$, and $4000 \mathrm{~m}$ ) from the same station to compare in situ data with the predicted jelly-POM attenuation with depth and the results using both the single-size-class constant-sinking model and the Martin curve formulations.

\section{Results}

Atlantic and Pacific Ocean $\mathrm{k}_{(T)}$ and $\mathrm{t}_{0.01}$ - In the following, we consider an idealized water column of varying depth according to real bottom topography, neglecting horizontal processes, vertical mixing, or seasonal variability. In the tropical regions of the Atlantic and Pacific Oceans from $30^{\circ} \mathrm{N}$ to $30^{\circ} \mathrm{S}$ and from $0 \mathrm{~m}$ to $100 \mathrm{~m}$, decay rates $k_{(T)}$ are high $\left(>4 \mathrm{~d}^{-1}\right)$, and decrease toward higher latitudes and greater depths, concomitant with lower temperatures to $<1 \mathrm{~d}^{-1}$ (Fig. 2). $k_{(T)}$ is relatively high $\left(0.5-1 \mathrm{~d}^{-1}\right)$ in the subarctic North Atlantic compared to the other high-latitude regions (Fig. 2). Below $1000 \mathrm{~m}, k_{(T)}$ remains roughly constant (between $<0.1 \mathrm{~d}^{-1}$ and $0.3 \mathrm{~d}^{-1}$ ) owing to the uniform temperature of the deep sea (Fig. 2B). Decay time scale $\left(t_{0.01}\right)$ varies inversely to decay rate and ranges from $<2 \mathrm{~d}$ in the tropical surface ocean to about $25 \mathrm{~d}$ below $1000 \mathrm{~m}$. The asymmetry in $k_{(T)}$ between the subarctic North Atlantic and other high-latitude regions is also reflected in $t_{0.01}$ (Fig. 2).

Model estimates of the jelly-POM export ratio-For scenario $1\left(z_{\mathrm{D}}=0 \mathrm{~m}\right)$, results for the export ratios $M\left(z_{\mathrm{R}}\right): M\left(z_{\mathrm{D}}\right)$ (Fig. 3) are similar in the Atlantic and Pacific Oceans at all depth intervals (from $0-100 \mathrm{~m}$ to 0 $5000 \mathrm{~m}$ ) at all latitudinal bands (with proportional changes based on $C$ from $100 \mathrm{~m} \mathrm{~d}^{-1}$ to $1500 \mathrm{~m} \mathrm{~d}^{-1}$ ), except in the $20^{\circ} \mathrm{N}-20^{\circ} \mathrm{S}$, where there is an $\sim 10-20 \%$ difference between the Atlantic and the Pacific (e.g., $100 \mathrm{~m}=63 \%$ in the Atlantic vs. $100 \mathrm{~m}=47 \%$ in the Pacific). Less than $30 \%$ of the material arrives at $5000 \mathrm{~m}$, and only in $40-60^{\circ} \mathrm{N}$ and $40-60^{\circ} \mathrm{S}$ significant amounts of material arrive below $3000 \mathrm{~m}(<20 \%$ elsewhere $)$. For $C<500 \mathrm{~m} \mathrm{~d}^{-1},<20 \%$ of the material arrives below $500 \mathrm{~m}$ (except $40-60^{\circ} \mathrm{N}$ and $40-60^{\circ} \mathrm{S}$ ). The following trend emerges: in the Atlantic (Fig. 3A), within $60-40^{\circ} \mathrm{N}$, between $28 \%$ and $85 \%$ of the sinking material arrives at $500 \mathrm{~m}$ (between $54 \%$ and $90 \%$ in the Pacific), using a $C$ between $300 \mathrm{~m} \mathrm{~d}^{-1}$ and $1500 \mathrm{~m} \mathrm{~d}^{-1}$. At $5000 \mathrm{~m}$ and for $C=800 \mathrm{~m} \mathrm{~d}^{-1}, 6 \%$ is left in the Atlantic (18\% in the Pacific), while for $C=1500 \mathrm{~m} \mathrm{~d}^{-1}, 23 \%$ and $32 \%$ are left, respectively, in both oceans. For any depth, the $M\left(z_{\mathrm{R}}\right): M\left(z_{\mathrm{D}}\right)$ estimates in the $60-40^{\circ} \mathrm{N}$ and $40-60^{\circ} \mathrm{S}$ latitude bands suggest a smaller percentage of jelly-POM reaching the deep North Atlantic compared to the deep South Atlantic, while in the Pacific (Fig. 3B) the interhemispheric trend is reversed. A sinking speed of $1500 \mathrm{~m} \mathrm{~d}^{-1}$ does not guarantee a large jelly-POM export ratio below $1000 \mathrm{~m}$ at any latitude ( $<35 \%$ in both oceans), except in the subpolar and polar areas $(<60 \%)$.

For scenario $2\left(z_{\mathrm{D}}\right.$ determined by vertical migration), the $M\left(z_{\mathrm{R}}\right): M\left(z_{\mathrm{D}}\right)$ reveals similar trends as in the first case study (shown only for the Atlantic Ocean; Fig. 4). However, higher percentages of jelly-POM reach $z_{\mathrm{R}}$ owing to an increasing (deeper) $z_{\mathrm{D}}$ used in this second case, and the thermal gradient approaching linearity below the thermocline. In all simulations $\left(z_{\mathrm{D}}=100 \mathrm{~m}, 500 \mathrm{~m}\right.$, or $1000 \mathrm{~m}$ ), the percentage change at any $z_{\mathrm{R}}$ within its corresponding latitude is similar $(<20 \%$ variability $)$, because of smaller latitudinal thermal variations below the euphotic zone. For any of the depth ranges used, a sinking velocity of $C=100 \mathrm{~m} \mathrm{~d}^{-1}$ delivers $<1 \%$ of the material at $z_{\mathrm{R}}$ exceeding $3000 \mathrm{~m}$. Using the deepest $z_{\mathrm{D}}$ $(500 \mathrm{~m}$ and $1000 \mathrm{~m})$, the portion of jelly-POM reaching $3000 \mathrm{~m}$ is largest. Using $C=1500 \mathrm{~m} \mathrm{~d}^{-1}$ for any $z_{\mathrm{D}},>20 \%$ of the jelly-POM reaches $z_{\mathrm{R}}$ at any latitude. For a $z_{\mathrm{D}}$ of $500 \mathrm{~m}$ or deeper, $>50 \%$ of the jelly-POM arrives at $z_{\mathrm{R}}$ at any latitude at fast sinking rates $\left(C=1500 \mathrm{~m} \mathrm{~d}^{-1}\right)$.

A comparison with the VERTIGO data from the ALOHA station and the Martin curve illustrates the dependence of the jelly-POM export ratio and the particle-based formulation on the sinking rate (Fig. 5). The jelly-POM export ratio remains below the Martin curve estimates up to $C=300 \mathrm{~m} \mathrm{~d}^{-1}$, and exceeds it in all cases for $C>300 \mathrm{~m} \mathrm{~d}^{-1}$ (Fig. 5). The particle-based estimates remain below the Martin curve predictions for all $k$ (except for $0.05 \mathrm{~d}^{-1}$ ) only for $C=20 \mathrm{~m} \mathrm{~d}^{-1}$. Particlebased calculations of the export ratio exceed the Martin curve only for sinking speeds of $\geq 1000 \mathrm{~m} \mathrm{~d}^{-1}$ (Fig. 5). The 
Table 3. Difference in export ratio $M\left(z_{\mathrm{R}}\right): M\left(z_{\mathrm{D}}\right)$ between a particle-based and the jelly-POM model at 5 depths and 10 sinking speeds $(C)$ normalized to $20 \mathrm{~m}$.

\begin{tabular}{|c|c|c|c|c|c|c|c|c|c|c|c|}
\hline \multirow[b]{2}{*}{$k^{*}$} & \multirow{2}{*}{$\begin{array}{c}\text { Depth } \\
(\mathrm{m})\end{array}$} & \multicolumn{10}{|c|}{ Model difference $\%=\left(\right.$ Particle $_{[\text {Export ratio] }}-$ Jelly $\left._{[\text {Export ratio] }}\right) \times 100 \dagger\left[C\left(\mathrm{~m} \mathrm{~d}^{-1}\right)\right]$} \\
\hline & & 20 & 50 & 100 & 200 & 300 & 500 & 800 & 1000 & 1500 & 2000 \\
\hline 0.05 & 150 & 68.73 & 86.07 & 92.65 & 92.73 & 86.65 & 72.08 & 55.54 & 47.85 & 35.33 & 27.93 \\
\hline 0.2 & 150 & 22.31 & 54.88 & 73.95 & 82.48 & 79.60 & 67.75 & 52.79 & 45.64 & 33.85 & 26.81 \\
\hline 0.5 & 150 & 2.35 & 22.31 & 47.11 & 65.14 & 67.00 & 59.64 & 47.52 & 41.37 & 30.95 & 24.62 \\
\hline 0.8 & 150 & 0.25 & 9.07 & 29.99 & 51.29 & 56.15 & 52.24 & 42.54 & 37.29 & 28.14 & 22.48 \\
\hline 1.2 & 150 & 0.01 & 2.73 & 16.40 & 37.07 & 44.00 & 43.34 & 36.32 & 32.12 & 24.52 & 19.69 \\
\hline 1.5 & 150 & 0.00 & 1.11 & 10.41 & 28.88 & 36.35 & 37.34 & 31.96 & 28.44 & 21.90 & 17.66 \\
\hline 2 & 150 & 0.00 & 0.25 & 4.85 & 18.72 & 25.91 & 28.45 & 25.20 & 22.67 & 17.70 & 14.37 \\
\hline 3 & 150 & 0.00 & 0.01 & 0.98 & 6.95 & 11.43 & 14.23 & 13.45 & 12.36 & 9.91 & 8.15 \\
\hline 4 & 150 & 0.00 & 0.00 & 0.12 & 1.39 & 2.65 & 3.69 & 3.71 & 3.47 & 2.86 & 2.38 \\
\hline 5 & 150 & 0.00 & 0.00 & -0.07 & -1.24 & -2.67 & -4.11 & -4.37 & -4.17 & -3.52 & -2.97 \\
\hline 0.05 & 300 & 47.24 & 74.08 & 86.07 & 92.23 & 92.05 & 84.66 & 71.04 & 63.32 & 49.16 & 39.93 \\
\hline 0.2 & 300 & 4.98 & 30.12 & 54.88 & 73.54 & 78.80 & 76.31 & 65.67 & 58.98 & 46.23 & 37.72 \\
\hline 0.5 & 300 & 0.06 & 4.98 & 22.31 & 46.70 & 57.58 & 61.70 & 55.80 & 50.88 & 40.64 & 33.45 \\
\hline 0.8 & 300 & 0.00 & 0.82 & 9.07 & 29.58 & 41.86 & 49.49 & 46.98 & 43.47 & 35.37 & 29.37 \\
\hline 1.2 & 300 & 0.00 & 0.07 & 2.73 & 15.99 & 27.04 & 36.29 & 36.66 & 34.58 & 28.82 & 24.20 \\
\hline 1.5 & 300 & 0.00 & 0.01 & 1.11 & 10.00 & 19.24 & 28.27 & 29.87 & 28.57 & 24.24 & 20.53 \\
\hline 2 & 300 & 0.00 & 0.00 & 0.24 & 4.44 & 10.46 & 17.73 & 20.13 & 19.69 & 17.19 & 14.76 \\
\hline 3 & 300 & 0.00 & 0.00 & 0.01 & 0.57 & 1.90 & 4.15 & 5.36 & 5.46 & 5.04 & 4.44 \\
\hline 4 & 300 & 0.00 & 0.00 & 0.00 & -0.29 & -1.25 & -3.31 & -4.79 & -5.07 & -4.91 & -4.44 \\
\hline 5 & 300 & 0.00 & 0.00 & 0.00 & -0.48 & -2.40 & -7.41 & -11.77 & -12.88 & -13.06 & -12.09 \\
\hline 0.05 & 500 & 28.65 & 60.65 & 77.88 & 88.06 & 90.45 & 86.91 & 75.95 & 68.87 & 54.87 & 45.22 \\
\hline 0.2 & 500 & 0.67 & 13.53 & 36.79 & 60.46 & 70.10 & 73.66 & 67.28 & 61.82 & 50.08 & 41.59 \\
\hline 0.5 & 500 & 0.00 & 0.67 & 8.21 & 28.46 & 41.91 & 52.44 & 52.19 & 49.22 & 41.18 & 34.71 \\
\hline 0.8 & 500 & 0.00 & 0.03 & 1.83 & 13.34 & 24.81 & 36.72 & 39.68 & 38.37 & 33.12 & 28.34 \\
\hline 1.2 & 500 & 0.00 & 0.00 & 0.25 & 4.79 & 11.98 & 21.90 & 26.26 & 26.22 & 23.56 & 20.54 \\
\hline 1.5 & 500 & 0.00 & 0.00 & 0.05 & 2.16 & 6.66 & 14.10 & 18.19 & 18.57 & 17.18 & 15.19 \\
\hline 2 & 500 & 0.00 & 0.00 & 0.00 & 0.48 & 2.01 & 5.32 & 7.68 & 8.12 & 7.87 & 7.12 \\
\hline 3 & 500 & 0.00 & 0.00 & 0.00 & -0.14 & -0.88 & -3.24 & -5.64 & -6.35 & -6.68 & -6.30 \\
\hline 4 & 500 & 0.00 & 0.00 & 0.00 & -0.19 & -1.43 & -6.38 & -12.76 & -15.13 & -17.11 & -16.75 \\
\hline 5 & 500 & 0.00 & 0.00 & 0.00 & -0.19 & -1.53 & -7.54 & -16.58 & -20.45 & -24.58 & -24.89 \\
\hline 0.05 & 1000 & 8.21 & 36.79 & 60.65 & 77.83 & 84.00 & 85.60 & 78.78 & 73.02 & 60.16 & 50.52 \\
\hline 0.2 & 1000 & 0.00 & 1.83 & 13.53 & 36.74 & 50.69 & 62.15 & 62.72 & 59.77 & 50.96 & 43.47 \\
\hline 0.5 & 1000 & 0.00 & 0.00 & 0.67 & 8.16 & 18.23 & 31.90 & 38.37 & 38.55 & 35.09 & 30.86 \\
\hline 0.8 & 1000 & 0.00 & 0.00 & 0.03 & 1.78 & 6.30 & 15.30 & 21.63 & 22.83 & 22.11 & 20.02 \\
\hline 1.2 & 1000 & 0.00 & 0.00 & 0.00 & 0.20 & 1.18 & 4.19 & 7.16 & 8.01 & 8.37 & 7.87 \\
\hline 1.5 & 1000 & 0.00 & 0.00 & 0.00 & 0.00 & 0.02 & 0.09 & 0.18 & 0.21 & 0.23 & 0.22 \\
\hline 2 & 1000 & 0.00 & 0.00 & 0.00 & -0.05 & -0.53 & -3.05 & -6.95 & -8.57 & -10.20 & -10.23 \\
\hline 3 & 1000 & 0.00 & 0.00 & 0.00 & -0.05 & -0.65 & -4.64 & -12.81 & -17.13 & -23.03 & -24.70 \\
\hline 4 & 1000 & 0.00 & 0.00 & 0.00 & -0.05 & -0.65 & -4.85 & -14.48 & -20.27 & -29.61 & -33.48 \\
\hline 5 & 1000 & 0.00 & 0.00 & 0.00 & -0.05 & -0.65 & -4.88 & -14.96 & -21.43 & -32.99 & -38.81 \\
\hline 0.05 & 4000 & 0.00 & 1.83 & 13.53 & 36.79 & 51.34 & 67.03 & 77.88 & 81.87 & 87.52 & 90.48 \\
\hline 0.2 & 4000 & 0.00 & 0.00 & 0.03 & 1.83 & 6.95 & 20.19 & 36.79 & 44.93 & 58.66 & 67.03 \\
\hline 0.5 & 4000 & 0.00 & 0.00 & 0.00 & 0.00 & 0.13 & 1.83 & 8.21 & 13.53 & 26.36 & 36.79 \\
\hline 0.8 & 4000 & 0.00 & 0.00 & 0.00 & 0.00 & 0.00 & 0.17 & 1.83 & 4.08 & 11.84 & 20.19 \\
\hline 1.2 & 4000 & 0.00 & 0.00 & 0.00 & 0.00 & 0.00 & 0.01 & 0.25 & 0.82 & 4.08 & 9.07 \\
\hline 1.5 & 4000 & 0.00 & 0.00 & 0.00 & 0.00 & 0.00 & 0.00 & 0.06 & 0.25 & 1.83 & 4.98 \\
\hline 2 & 4000 & 0.00 & 0.00 & 0.00 & 0.00 & 0.00 & 0.00 & 0.00 & 0.03 & 0.48 & 1.83 \\
\hline 3 & 4000 & 0.00 & 0.00 & 0.00 & 0.00 & 0.00 & 0.00 & 0.00 & 0.00 & 0.03 & 0.25 \\
\hline 4 & 4000 & 0.00 & 0.00 & 0.00 & 0.00 & 0.00 & 0.00 & 0.00 & 0.00 & 0.00 & 0.03 \\
\hline 5 & 4000 & 0.00 & 0.00 & 0.00 & 0.00 & 0.00 & 0.00 & 0.00 & 0.00 & 0.00 & 0.00 \\
\hline
\end{tabular}

* $k$ data were increased from 0.05 to 5 to approximate the variability modeled as a function of jelly-POM decomposition (Fig. 2).

$\dagger$ Data calculated as the difference between $M\left(z_{\mathrm{R}}\right): M\left(z_{\mathrm{D}}\right)$ from Kriest and Oschlies (2008) particle-based parameterization and the jelly-POM parameterization presented in this paper. Bold font indicates that the value is within $25 \%$ of the jelly-POM model. Positive and negative values are over and underestimations from the particle-based model in relation to the jelly-POM model.

largest differences between the jelly-POM formulation and the particle-based export model are encountered in the export ratio between $150 \mathrm{~m}$ and $300 \mathrm{~m}$ for $k<1.2 \mathrm{~d}^{-1}$ (Table 3). Deeper, the differences become smaller as $k$ increases from $0.05 \mathrm{~d}^{-1}$ to $5 \mathrm{~d}^{-1}$. Differences between the two models are smaller for single-particle decay rates closer to those predicted by the temperature-dependent $k_{(T)}$ in the jelly-POM formulation. The particle-based model can 


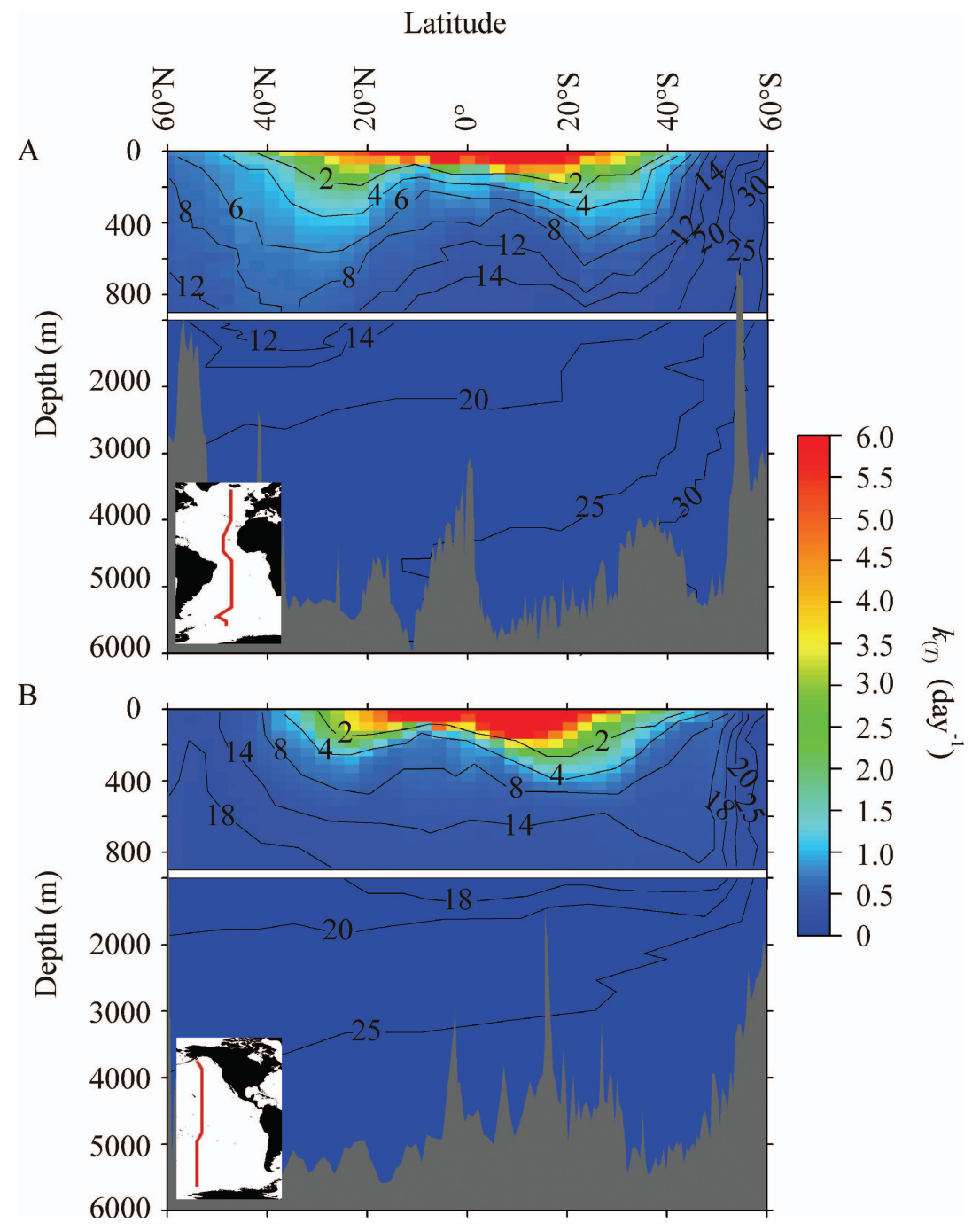

Fig. 2. The modeled $k_{(T)}$ as function of temperature in (A) Atlantic Ocean, and (B) Pacific Ocean, based on temperature fields from hydrographic transects from $0 \mathrm{~m}$ to $6000 \mathrm{~m}$. Overlaid are contours of the $t_{0.01}$ (in days). From $0 \mathrm{~m}$ to $900 \mathrm{~m}$, the scale is spaced at intervals of $200 \mathrm{~m}$ (for magnification), while from $1000 \mathrm{~m}$ to $6000 \mathrm{~m}$ it is spaced at $1000-\mathrm{m}$ intervals. Note that there are no $k$ data on the tropics to verify $k>2$; thus, results are calculated from Eq. 2.

reproduce measured POM\% from ALOHA station sediment-trap data within $20 \%$ for $C=20-50 \mathrm{~m} \mathrm{~d}^{-1}$ and a decay rate of $k=0.05 \mathrm{~d}^{-1}$, and similarly well if both sinking velocity and decay rate increase by the same factor (Fig. 5). For ratios predicted by the jelly-POM export-ratio model, observed POM\% can be reproduced at all depths within $\sim 5 \%$ using $C=1500 \mathrm{~m} \mathrm{~d}^{-1}$, and within $\sim 20 \%$ using $C=1000 \mathrm{~m} \mathrm{~d}^{-1}$ and $2000 \mathrm{~m} \mathrm{~d}^{-1}$, while the model underestimates the observed export ratio for lower sinking velocities.

\section{Discussion}

The active transport of living gelatinous material caused by vertical migration affects the death depth $z_{\mathrm{D}}$ and determines the temperature at which export and decomposition commence. The complex migratory response (gov- erning $\left.z_{\mathrm{D}}\right)$ is not included in particle-based export formulations, but similar considerations are needed for other migratory taxa enhancing POC export at depth (Steinberg et al. 2007). Variability in the depth of the euphotic zone may have to be considered to explain confounding effects of particle fluxes measured at the same depth but originating at different depths (Buesseler and Boyd 2009). Similarly, information about the patterns of $z_{\mathrm{D}}$ is required to constrain regional and latitudinal estimates of jelly-POM export. The scarcity of field data on the organisms' $z_{\mathrm{D}}$ prevents an accurate parameterization in the model. However, $z_{\mathrm{D}}$ must lie within the vertical migration range (likely near the lower limit), which may be close to the seabed in the case of salps and pyrosomids (Wiebe et al. 1979). The four death depths considered here $\left(z_{\mathrm{D}}=20 \mathrm{~m}, 100 \mathrm{~m}, 500 \mathrm{~m}, 1000 \mathrm{~m}\right)$ correspond to the depths at which different taxa occur and migrate (Figs. 3, 

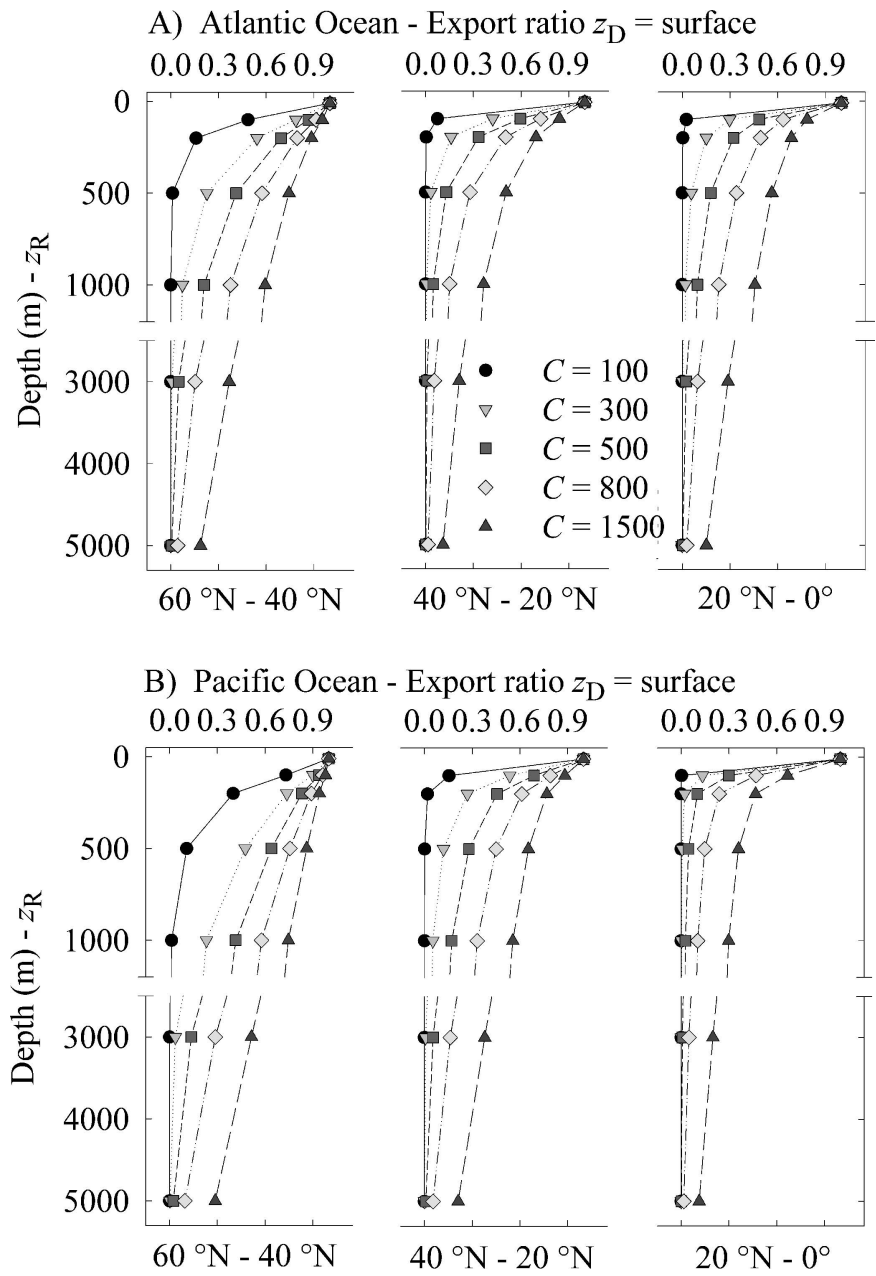

Fig. 3. Results from the simulation of the jelly-POM export ratio $M\left(z_{\mathrm{R}}\right): M\left(z_{\mathrm{D}}\right)$ divided in latitudinal ranges $\left(60^{\circ} \mathrm{N}\right.$ to $0^{\circ}$ shown as an example, and $0^{\circ}$ to $60^{\circ} \mathrm{S}$ described in results). Temperature divisions are averaged over latitudinal ranges and depth intervals: (A) in the Atlantic Ocean, and (B) in the Pacific Ocean (Table 2). A matrix of six depth intervals between the surface $\left(z_{\mathrm{D}}=0\right)$ and the reference depth $\left(z_{\mathrm{R}}=100 \mathrm{~m}, 200 \mathrm{~m}\right.$, $500 \mathrm{~m}, 1000 \mathrm{~m}, 3000 \mathrm{~m}$, and $5000 \mathrm{~m})$ and five sinking velocities $(C$; $100 \mathrm{~m} \mathrm{~d}^{-1}, 300 \mathrm{~m} \mathrm{~d}^{-1}, 500 \mathrm{~m} \mathrm{~d}^{-1}, 800 \mathrm{~m} \mathrm{~d}^{-1}$, and $1500 \mathrm{~m} \mathrm{~d}^{-1}$ ) was used.

4). The actual distribution of the start of jelly falls in space and time is complex. Other death depths $\left(z_{\mathrm{D}}=1000 \mathrm{~m}\right)$ apply to situations where animals die on the deeper range of their vertical migration (e.g., Pyrosoma atlanticum in Roe et al. [1990] migrating down to $800 \mathrm{~m}$ and below). As a generalization (including Cnidaria), several variables trigger the onset of jelly falls: high levels of primary production clogging the feeding apparatus of thaliaceans (Perissinotto and Pakhomov 1998), changes in temperature (Gatz et al. 1973), ageing of blooms and food exhaustion (Purcell et al. 2001), grazing and predation damage (Arai 2005), and parasitism (injury and viral) infections during ageing blooms (Mills 1993). We do not include biological controls on jelly falls in the model, because we are concerned only with the subsequent fate of the jelly-POM.
Our model assumes that the amount of gelatinous material arriving at $z_{\mathrm{R}}$ is mainly controlled by the temperature dependence of remineralization $\left(Q_{10}=4.28\right.$; Table 2) and the sinking speed. The temperature at $z_{\mathrm{D}}$ is important in the euphotic zone (Fig. 4), but, at high sinking velocities (above $500 \mathrm{~m} \mathrm{~d}^{-1}$ ), jelly-POM can reach lower temperatures below the thermocline relatively fast, which reduces the overall remineralization rate. The interaction among the three parameters (death depth, temperature dependence, and sinking speed) is, thus, fundamental in predicting the jelly-POM export ratio. According to our model, gelatinous material sinking from the euphotic zone $\left(z_{\mathrm{D}}<100 \mathrm{~m}\right)$ is likely to reach the seabed at temperate and high latitudes (pole-ward of $40^{\circ} \mathrm{N}$ and $40^{\circ} \mathrm{S}$; Figs. 2, 3), while in tropical or subtropical areas, material is not likely to sink below $500 \mathrm{~m}$ before being completely remineralized (except at sinking speeds above $800 \mathrm{~m} \mathrm{~d}^{-1}$ ). Greater death depths $\left(z_{\mathrm{D}}=500-1000 \mathrm{~m}\right)$, representative of deep migratory species, allow significant amounts of jelly-POM to reach $3000 \mathrm{~m}$ (and below) at any latitude for sinking speeds above $500 \mathrm{~m} \mathrm{~d}^{-1}$ (jelly-POM = 20-87\%; Fig. 4). This prediction is concomitant to visual observations of living and moribund salps close to the seabed in the North Atlantic and deposition of dead corpses (Cacchione et al. 1978). Living salp chains were observed off the Antarctic Peninsula on the seabed at $800 \mathrm{~m}$ (Gili et al. 2006); thus, it is plausible that they die and decompose in the vicinity. Remineralization would start on the seabed itself (at low temperatures $\left[<2-4^{\circ} \mathrm{C}\right]$ ), therefore delaying decomposition (Fig. 2). The observations of $P$. atlanticum carcasses on the seabed below $5000 \mathrm{~m}$ (likely sinking from $500 \mathrm{~m}$ to $800 \mathrm{~m}$ ) further confirm our model results (Fig. 6). A deep $z_{\mathrm{D}}$ combined with fast sinking rates allows transfer to the seabed, although in a decaying state. The observed carcasses stayed $17 \mathrm{~d}$ at the seabed before being completely decomposed (Fig. 6), in agreement with our model giving $k_{(T)} \approx 0.2, t_{0.01} \approx 22 \mathrm{~d}$ (Fig. 2 ).

The depth of the seabed relative to the remineralization depth eventually determines the amount and the state of the material found. The two major jelly falls studied to date were sampled in tropical areas below $1000 \mathrm{~m}$ (Arabian Sea: Billett et al. 2006; Gulf of Guinea: Lebrato and Jones 2009), while no other major deposition has been recorded in the tropics (M. Lebrato unpubl.). A deep $z_{\mathrm{D}}$ linked to a wide vertical migration range and fast sinking rates $\left(>800 \mathrm{~m} \mathrm{~d}^{-1}\right)$ might allow the material to arrive at the seabed. If $z_{\mathrm{D}}$ is located within a few meters of the seabed, decomposition starts at the seabed itself. In oxygendeficient areas of the Arabian Sea and the Gulf of Guinea, oxygen could limit remineralization in the first $1000 \mathrm{~m}$. Temperature drops below $10-12^{\circ} \mathrm{C}$ below the sharp thermocline in these tropical areas (Table 2), keeping decay rates $\left[k_{(T)}\right]$ small $\left(<0.8 \mathrm{~d}^{-1}\right)$. Jelly falls are studied by visual surveys using video and photography, which does not allow estimation of the gelatinous POM\% (to compare with living biomass). Visual observation of a jelly fall also cannot provide information on its stoichiometry, which prevents comparisons with model export predictions. Based on our model, the most likely material to arrive at the seabed is, therefore, from taxa that perform large vertical 


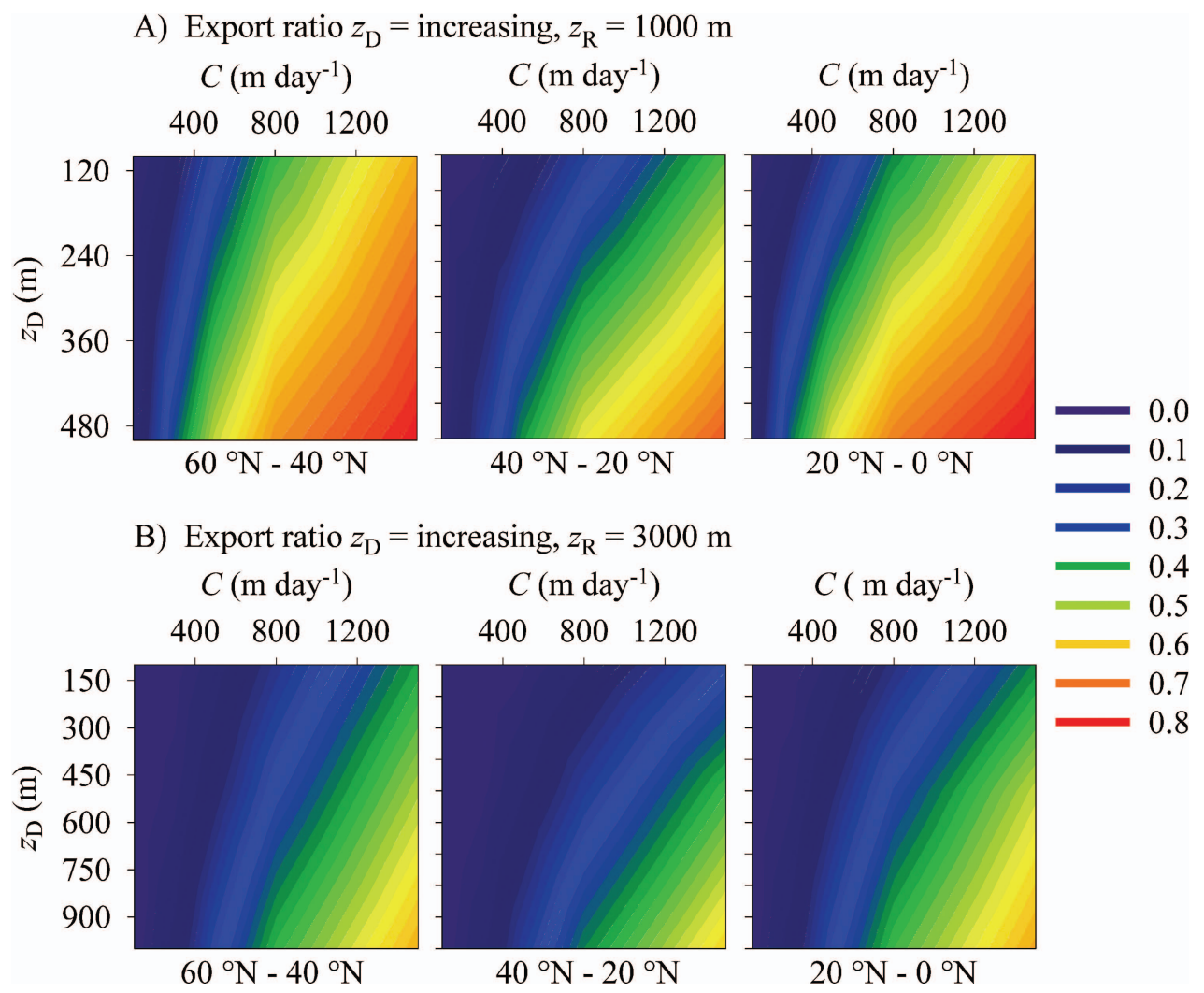

Fig. 4. Results from the simulation of the jelly-POM export ratio $M\left(z_{\mathrm{R}}\right): M\left(z_{\mathrm{D}}\right)$ : (A) reference depth $z_{\mathrm{R}}=1000 \mathrm{~m}$ (death depth $z_{\mathrm{D}}=100 \mathrm{~m}$ and $500 \mathrm{~m}$ ), and $(\mathrm{B})$ reference depth $z_{\mathrm{R}}=$ $3000 \mathrm{~m}$ (death depth $z_{\mathrm{D}}=100 \mathrm{~m}, 500 \mathrm{~m}$, and $1000 \mathrm{~m}$ ) using an increasing sinking speed from $100 \mathrm{~m} \mathrm{~d}^{-1}$ to $1500 \mathrm{~m} \mathrm{~d}^{-1}$. Data are divided in three major latitudinal intervals only for the northern hemisphere in the Atlantic Ocean.

migrations (salps and pyrosomids) and whose $z_{D}$ is below the thermocline and/or very close to the bottom. The decay time scale $\left(t_{0.01}\right)$ at depths below $1000 \mathrm{~m}$ amount to $15-30 \mathrm{~d}$ (Fig. 2) across the studied transects, providing a reasonable time window to encounter this material.

Besides variations in $z_{\mathrm{D}}$ and sedimentation rates, differences in stoichiometry and body size may explain why thaliaceans and scyphozoans accumulate on the sea floor and hydrozoans and ctenophores do not. Hydrozoans and ctenophores typically have a lower $\mathrm{C}: \mathrm{N}$ than thaliaceans and scyphozoans (Lucas et al. 2011) and the greater lability of the hydrozoans and ctenophore tissues facilitates a rapid remineralization. Most hydrozoans and many ctenophores are smaller than thaliaceans (especially pyrosomids) and scyphozoans, which may reduce the sinking rate. Jelly-POM should normally reach the seafloor on temperate and subpolar shelves and continental slopes, but is also consumed by macro and megafauna in the benthic communities (Yamamoto et al. 2008).

Model limitations: Factors governing jelly-POM remineralization - Gelatinous material is remineralized by microzooplankton (Titelman et al. 2006) and by microbial action (Condon and Steinberg 2008). Hence, differences in rates of remineralization of gelatinous material in deep and shallow waters are not only attributable to temperature but also to the in situ microbial community. Thus, while jelly-POM remineralization is certainly more complex than presented here, the model provides the theoretical grounds for an objective assessment of gelatinous biomass contribution to POM export and its incorporation in biogeochemical models. Additional factors governing the export ratio, beyond $k_{(T)}$, temperature, and sinking rate are pressure, non-Redfield stoichiometry (Frost et al. 2002), oxygen concentration, the abundance and biomass of large pelagic fauna (Arai 2005), physical forcing, and the microbial community (Titelman et al. 2006). Our model parameterizes the temperature effect, assuming that the microbial activity and pressure effects are included in this formulation. Improved formulations will require quantification of gelatinous material decomposition under different temperature and pressure regimes, with different microbial communities.

Treatment in biogeochemical models - Jelly falls and their biogeochemical feedbacks differ from other POM sources because of their episodic nature, their likely initiation from below the euphotic zone, and the size classes involved. In contrast to fecal pellets and mucilaginous detritus, which provide an almost continuous small flux (Robison et al. 2005), jelly falls deliver a large and sudden pulse of material after their demise (Lebrato and Jones 2009). This is 


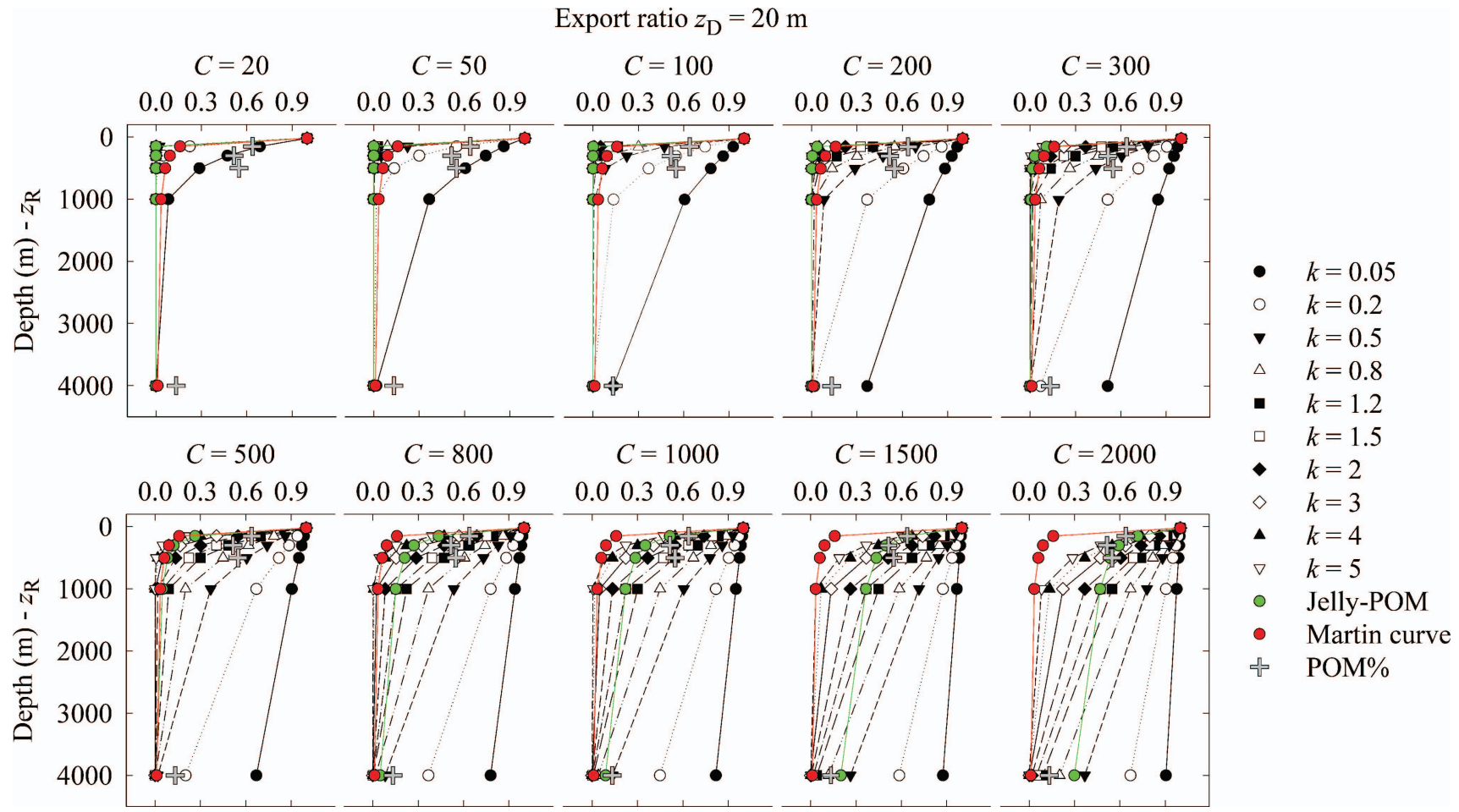

Fig. 5. A comparison of the jelly-POM export ratio $M\left(z_{\mathrm{R}}\right): M\left(z_{\mathrm{D}}\right)$ with the Martin curve (Martin et al. 1987) and a particle-based parameterization (Kriest and Oschlies 2008). Results are presented for five depths with the export ratio normalized to $20 \mathrm{~m}$. Ten sinking rates are used, ranging from $20 \mathrm{~m} \mathrm{~d}^{-1}$ to $2000 \mathrm{~m} \mathrm{~d}^{-1}$. Temperature data $[T(z)]$ are from the Vertical Transport In the Global Ocean (VERTIGO) project at the ALOHA station $\left(22.75^{\circ} \mathrm{N}, 158^{\circ} \mathrm{W}\right.$; Table 2$)$. The POM\% data originate from neutrally buoyant sediment traps (Buesseler et al. 2007).
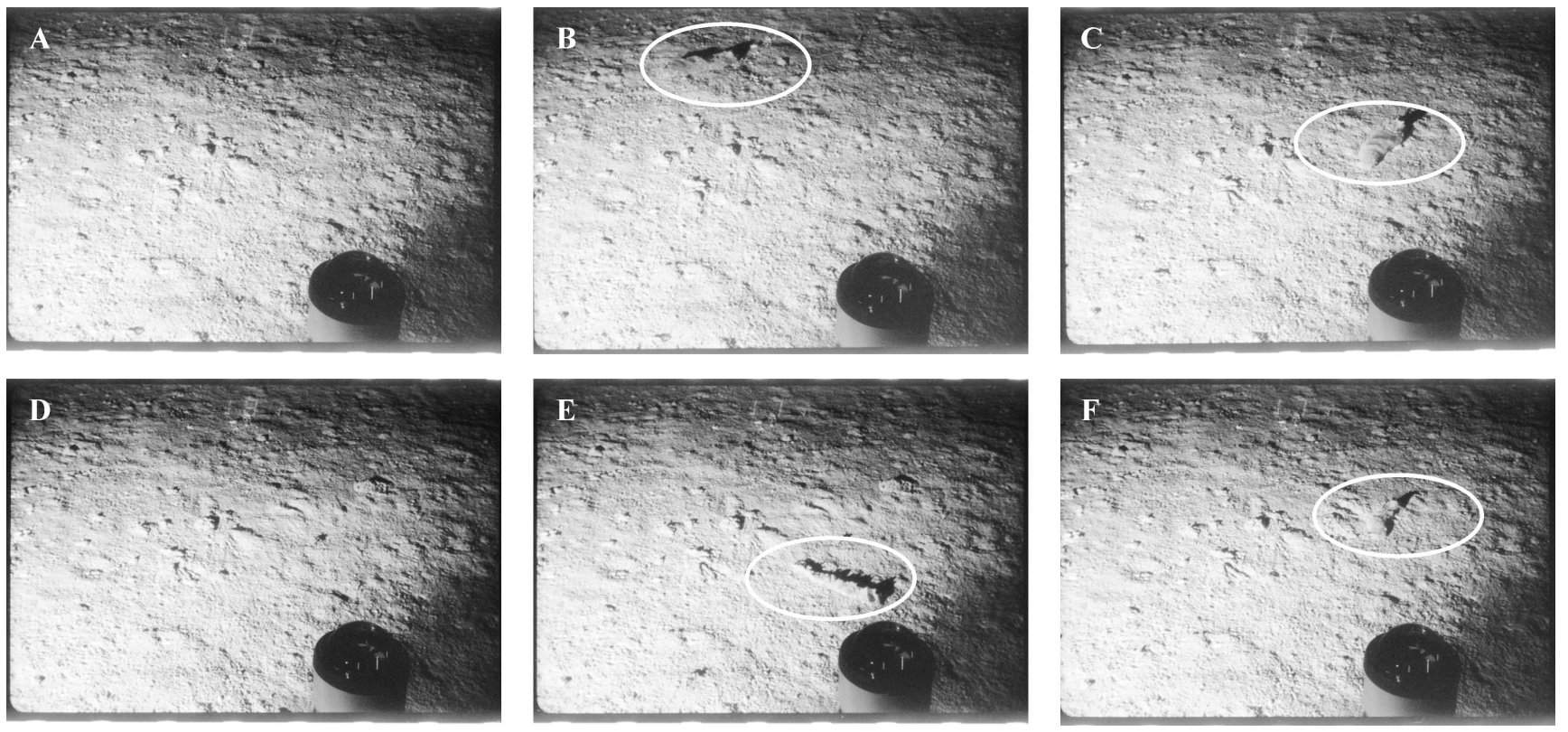

Fig. 6. A photographic sequence showing the settlement, decomposition, and disappearance of a Pyrosoma atlanticum carcass in the Madeira Abyssal Plain (NE Atlantic) at $5433 \mathrm{~m}$. The images were obtained with an instrument called 'Bathysnap' (time-lapse photography) in a deployment at $31.26^{\circ} \mathrm{N}, 25.42^{\circ} \mathrm{W}$, from 19 July to 19 November 1985 ( $123 \mathrm{~d}$ ). Each frame interval equals 512 min, and the area of each image is $2 \mathrm{~m}^{2}$. Circles in red show the carcass. (A) Initial view of the seabed with no carcass on frame 133 (04 Sep 1985 ), (B) settlement of carcass on frame 134 (04 Sep 1985), (C) start of decomposition of carcass on frame 161 (13 Sep 1985), (D) carcass showing clear signs of degradation on frame 176 (19 Sep 1985), (E) carcass completely degraded on frame 179 (20 Sep 1985), and (F) carcass disappeared or completely decomposed on frame 180 (21 Sep 1985). The residence time of the carcass was $16.71 \mathrm{~d} \pm 0.35 \mathrm{~d}$, with the error indicating the time interval for which there is no data. Degradation can be visually confirmed over time. Images courtesy of R. S. Lampitt. 
analogous to phytodetritus pulses after the spring bloom in temperate latitudes.

By changing the sinking velocity and the decay rate $(k)$, we can simulate the export ratio for ALOHA at depth by both the particle-based (Kriest and Oschlies 2008) and the jelly-POM model. The Martin curve can simulate jellyPOM remineralization and/or the particle-based model for sinking velocities smaller than $C=200 \mathrm{~m} \mathrm{~d}^{-1}$ and remineralization rates larger than $k=0.5 \mathrm{~d}^{-1}$. The particle-based model uses a constant decay rate with varying sinking speed, which we applied to a wide $k$ spectrum $\left(0.05-5 \mathrm{~d}^{-1}\right)$ to mimic the $k_{(T)}$ dependency (Table 2; Fig. 5). Inter-model differences (Table 2) in the export ratio decrease with depth ( $150 \mathrm{~m}$ to $4000 \mathrm{~m}$ ) because of the lower temperature variability. This reduces the difference between the $k_{(T)}$ of the jelly-POM model and the $k$ of the particle-based model.

In principle, it should be relatively straightforward to augment parameterizations of POM export and remineralization used in current three-dimensional marine biogeochemical models. This could be done by an extra (largesize) detritus compartment, representing jelly-POM. The typical sinking speeds $\left(5-50 \mathrm{~m} \mathrm{~d}^{-1}\right)$ applied in numerical model formulations to represent the sinking of 'ordinary' detritus (Oschlies and Garcon 1999) and remineralization rates $\left(0.1-0.3 \mathrm{~d}^{-1}\right.$, see Fig. $\left.1 \mathrm{~A}\right)$, do not generally apply to jelly-POM. Remineralization rates of ordinary detritus are used as functions of ambient temperature in some models (Schmittner et al. 2008), and this could be expanded to jelly-POM. The jelly-POM parameterization format could also be applied to describe other POM compartments, provided that the temperature dependence of $k$ (Fig. 1A) is known. Some formulations of organic matter export suggest using constant decay rates as a function of depth, with an exponential attenuation of the flux (Lutz et al. 2002). This assumption induces a large flux attenuation in the upper ocean in models, not representing sediment-trap data. This occurs for jelly-POM export when not using appropriate sinking speeds, and/or $k$ data (Table 3; Fig. 5). We propose that the use of $k$ should include a temperature dependency for any particle to mimic vertical profiles accounting for different starting depths. The POM size spectrum is much larger than we currently measure in sediment traps. The use of our formulations might enable the application of the same metrics with different parameters to a much wider range of particles. For jelly-POM, robust hypotheses about what triggers jelly blooms, death, and falls await development. They should eventually be combined with the theory presented here about the fate of jelly-POM to reach a better understanding of the role of gelatinous zooplankton in marine biogeochemical cycles.

\section{Acknowledgments}

This work was funded by the Kiel Cluster of Excellence 'The Future Ocean' (D1067/87), and also by the 'European project on Ocean Acidification' (which received funding from the European Community's Seventh Framework Programme [FP7/2007-2013] under grant agreement 211384) to M.L. We thank anonymous reviewers for their comments, which improved the final version of this paper.

\section{References}

Andersen, V., And J. SArdou. 1994. Pyrosoma atlanticum (Tunicata: Thaliacea): Diel migration and vertical distribution as a function of colony size. J. Plankton Res. 16: 337-349, doi:10.1093/plankt/16.4.337

Apstein, C. 1910. Hat ein Organismus in der Tiefe Gelebt, in der er gefischt ist? Int. Rev. Hydrobio. Hydrograph. 3: 17-33. [Did the organism live at the depth in which it was caught?], doi:10.1002/iroh.19100030109

Arai, M. N. 2005. Predation on pelagic coelenterates: A review. J. Mar. Biol. Assoc. U.K. 85: 523-536, doi:10.1017/ S0025315405011458

Billett, D. S. M., B. J. Bett, C. L. Jacobs, I. P. Rouse, and B. D. Wigham. 2006. Mass deposition of jellyfish in the deep Arabian Sea. Limnol. Oceanogr. 51: 2077-2083, doi:10.4319/ 10.2006.51.5.2077

Buesseler, K. O., And P. W. Boyd. 2009. Shedding light on processes that control particle export and flux attenuation in the twilight zone of the open ocean. Limnol. Oceanogr. 54: 1210-1232, doi:10.4319/lo.2009.54.4.1210

, AND OTHERS. 2007. Revisiting carbon flux through the ocean's twilight zone. Science 316: 567-570, doi:10.1126/ science. 1137959

Cacchione, D. A., G. T. Rowe, and A. Malahoff. 1978. Submersible investigation of outer Hudson submarine canyon, p. 52-50. In D. J. Stanley and G. Kelling [eds.], Sedimentation in canyons, fans and trenches. Stroudsburg Pennsylvania, Dowden, Hutchinson and Ross.

Condon, R. H., and D. K. Steinberg. 2008. Development, biological regulation, and fate of ctenophore blooms in the York River estuary, Chesapeake Bay. Mar. Ecol. Prog. Ser. 369: 153-168, doi:10.3354/meps07595

- P. A. del Giorgio, T. C. Bouvier, D. A. Bronk, W. M. Graham, and H. W. Ducklow. 2011. Jellyfish blooms result in a major microbial respiratory sink of carbon in marine systems. Proc. Natl. Acad. Sci. USA 108: 10225-10230, doi:10.1073/pnas.1015782108

Franqueville, C. 1971. Macroplancton profond (invertébrés) de la Méditerranée nord-occidentale. Tethys 3: 11-56. [Deep macroplankton (invertebrates) of the northwest Mediterranean Sea].

Frost, P. C., R. S. Stelzer, G. A. Lamberti, and J. J. Elser. 2002. Ecological stoichiometry of trophic interactions in the benthos: Understanding the role of $\mathrm{C}: \mathrm{N}: \mathrm{P}$ ratios in littoral and lotic habitats. J. North Am. Benthol. Soc. 21: 515-528, doi: $10.2307 / 1468427$

Fuji, M. F., S. Murashige, Y. Ohnishi, A. Yuzawa, H. Miyasaka, Y. Suzuki, and H. Komiyama. 2002. Decomposition of phytoplankton in seawater. Part I: Kinetic analysis of the effect of organic matter concentration. J. Oceanogr. 58: 433-438, doi:10.1023/A:1021296713132

Gatz, A. J., V. S. Kennedy, And J. A. Minursky. 1973. Effects of temperature on activity and mortality of the Scyphozoan medusa Chrysaora quinquecirrha. Chesapeake Sci. 14: 171-180, doi:10.2307/1350603

Gili, J. M., S. Rossi, F. Pages, C. Orejas, N. Teixido, P. J. LopezGonzalez, And W. E. Arntz. 2006. A new trophic link between the pelagic and benthic systems on the Antarctic shelf. Mar. Ecol. Prog. Ser. 322: 43-49, doi:10.3354/ meps 322043

Golden Software. 2002. Surfer: A powerful contouring, gridding, and surface mapping package for scientists and engineers, version 8. 01. Golden Software. Available from http://www.goldensoftware.com/. 
Huwer, B., M. Storr-Paulsen, H. U. RiisgÅrd, and H. Haslob. 2008. Abundance, horizontal and vertical distribution of the invasive ctenophore Mnemiopsis leidyi in the central Baltic Sea, November 2007. Aquat. Invas. 3: 113-124, doi:10.3391/ ai.2008.3.2.1

Iguchi, N., R. Ishikawa, O. Sato, T. Onishi, and T. Maeda. 2006. Decomposition rate of the giant jellyfish Nemopilema nomurai in Sado Island. [Translated from Japanese.] FRA, Japan Sea National Fisheries Research Institute report [accessed 2009 June 2]. Available from http://jsnfri.fra.affrc. go.jp/Kurage/kurage_hp18/Sado_bunkai.pdf.

Kriest, I., AND A. Oschlies. 2008. On the treatment of particulate organic matter sinking in large-scale models of marine biogeochemical cycles. Biogeosciences 5: 55-72, doi:10.5194/ bg-5-55-2008

Kuenen, P. H. 1950. Marine geology. John Wiley.

Lebrato, M., And D. O. B. Jones. 2009. Mass deposition event of Pyrosoma atlanticum carcasses off Ivory Coast (West Africa). Limnol. Oceanogr. 54: 1197-1209, doi:10.4319/1o.2009. 54.4.1197

Lucas, C. H., K. A. Pitt, J. E. Purcell, M. Lebrato, and R. H. Condon. 2011. What's in a jellyfish? Proximate and elemental composition and biometric relationships for use in biogeochemical studies. Ecology 92: 1704.

Lutz, M., R. Dunbar, and K. Caldeira. 2002. Regional variability in the vertical flux of particulate organic carbon in the ocean interior. Glob. Biogeochem. Cycles 16: 1037-1055, doi:10.1029/2000GB001383

Martin, J. H., G. A. Knauer, D. M. Karl, and W. W. Broenkow. 1987. VERTEX: Carbon cycling in the northeast Pacific. Deep-Sea Res. Part I 34: 267-285.

McDonnell, A. M. P., AND K. O. Buesseler. 2010. Variability in the average sinking velocity of marine particles. Limnol. Oceanogr. 55: 2085-2096, doi:10.4319/lo.2010.55.5.2085

Mills, C. E. 1993. Natural mortality in NE Pacific coastal hydromedusae: Grazing predation, wound healing and senescence. Bull. Mar. Sci. 53: 194-203.

Oschlies, A., And V. Garcon. 1999. An eddy-permitting coupled physical-biological model of the North Atlantic, I, Sensitivity to advection numerics and mixed layer physics. Glob. Biogeochem. Cycles 13: 135-160, doi:10.1029/98GB02811

Perissinotto, R., and E. A. Pakhomov. 1998. Contribution of salps to carbon flux of marginal ice zone of the Lazarev Sea, Southern Ocean. Mar. Biol. 131: 25-32, doi:10.1007/ s002270050292

Pitt, K. A., D. T. Welsh, and R. H. Condon. 2009. Influence of jellyfish blooms on carbon, nitrogen, and phosphorus cycling and plankton production. Hydrobiologia 616: 133-149, doi:10.1007/s10750-008-9584-9

Ploug, H., and H. P. Grossart. 2000. Bacterial growth and grazing on diatom aggregates: Respiratory carbon turnover as a function of aggregate size and sinking velocity. Limnol. Oceanogr. 45: 1467-1475, doi:10.4319/lo.2000.45.7.1467

Purcell, J. E., W. M. Graham, and H. J. Dumont. 2001. Jellyfish blooms: Ecological and societal importance. Developments in hydrobiology. Kluwer Academic.

Robison, B. H., K. R. Reisenbichler, and R. E. Sherlock. 2005. Giant larvacean houses, rapid carbon transport to the deepsea floor. Science 308: 1609-1611, doi:10.1126/science. 1109104
Roe, H. S. J., M. V. Angel, J. Badcock, P. Domanski, P. T. James, P. R. Pugh, and M. H. Thurston. 1984. The diel migrations and distributions within a mesopelagic community in the northeast Atlantic. Prog. Oceanogr. 13: 245-511, doi:10.1016/0079-6611(84)90010-7

, D. S. M. Billett, And R. S. Lampitt. 1990. Benthic/ midwater interactions on the Madeira Abyssal Plain; evidence for biological transport pathways. Prog. Oceanogr. 24: 127-140, doi:10.1016/0079-6611(90)90025-W

Schmittner, A., A. Oschlies, H. D. Matthews, And E. Galbraith. 2008. Future changes in climate, ocean circulation, ecosystems and biogeochemical cycling simulated for a business-as-usual $\mathrm{CO}_{2}$ emission scenario until year $4000 \mathrm{AD}$. Glob. Biogeochem. Cycles 22: GB1013, doi:10.1029/ 2007GB002953

Sempere, R., S. C. Yoro, F. Van Wambeke, and B. Charriere. 2000. Microbial decomposition of large organic particles in the northwestern Mediterranean Sea: An experimental approach. Mar. Ecol. Prog. Ser. 198: 61-72, doi:10.3354/ meps198061

Steinberg, D. K., B. A. S. Van Mooy, K. O. Buesseler, P. W. Boyd, T. Kobari, and D. M. Karl. 2007. Bacterial vs. zooplankton control of sinking particle flux in the ocean's twilight zone. Limnol. Oceanogr. 53: 1327-1338, doi:10.4319/ 10.2008.53.4.1327

Sudo, R., H. Ohtake, and S. Aiba. 1978. Some ecological observation on the decomposition of periphytic algae and aquatic plants. Water Res. 12: 179-184, doi:10.1016/0043-1354 (78) $90006-4$

Titelman, J., L. Riemann, T. A. Sornes, T. Nilsen, P. GrieksPoOR, AND U. BAMSTEDT. 2006. Turnover of dead jellyfish, stimulation and retardation of microbial activity. Mar. Ecol. Prog. Ser. 325: 43-58, doi:10.3354/meps 325043

Turner, J. T. 2002. Zooplankton faecal pellets, marine snow and sinking phytoplankton blooms. Aquat. Microbiol. Ecol. 27: 57-102, doi:10.3354/ame027057

Walsby, A. E., And A. Xypolyta. 1977. The form resistance of chitan fibres attached to the cells of Thalassiosira fluviatilis Hustedt. Br. Phycol. J. 12: 215-223, doi:10.1080/ 00071617700650231

West, E. J., D. T. Welsh, and K. A. Pitt. 2009. Influence of decomposing jellyfish on sediment oxygen demand and nutrient dynamics. Hydrobiologia 616: 151-160, doi:10.1007/ s10750-008-9586-7

Wiebe, P. H., L. P. Madin, L. R. Haury, G. R. Harbison, and L. M. Philbin. 1979. Diel vertical migration by Salpa aspera and its potential for large-scale particulate organic matter transport to the deep-sea. Mar. Biol. 53: 249-255, doi:10.1007/BF00952433

YAMAмото, J., AND OTHERS. 2008. Transportation of organic matter to the sea floor by carrion falls of the giant jellyfish Nemopilema nomurai in the Sea of Japan. Mar. Biol. 153: 311-317, doi:10.1007/s00227-007-0807-9

Associate editor: Thomas Kiørboe

Received: 02 March 2011 Accepted: 05 July 2011 Amended: 07 July 2011 